\title{
Karakteristik reproduksi ikan sidat Anguilla bicolor McClelland, 1844 yang diinduksi GNRH-analog
}

[Reproductive characteristic of Anguilla bicolor McCleland, 1844 which inducted by administration of $\mathrm{GnRh}-$ Analog]

\author{
Farida Nur Rachmawati ${ }^{1}$, Untung Susilo ${ }^{1}$, Muslih $^{2}$ \\ ${ }^{1}$ Fakultas Biologi Universitas Jenderal Soedirman \\ ${ }^{2}$ Fakultas Perikanan dan Kelautan Universitas Jenderal Soedirman \\ Jln dr. Soeparno No. 63 Purwokerto 53122 \\ Diterima: 5 Oktober 2016; Disetujui: 4 April 2017
}

\begin{abstract}
Abstrak
Ikan sidat Anguilla bicolor McClelland sulit matang gonad dalam kondisi budi daya, karena rendahnya kadar gonadotropin pituitari. Oleh karena itu untuk memacu pematangan gonad ikan sidat dalam kondisi budi daya perlu ditambahkan gonadotropin secara eksogen. Tujuan penelitian ini adalah mengkaji pengaruh induksi GnRH-analog terhadap pematangan gonad ikan sidat berdasarkan perubahan nilai indeks mata, indeks kematangan gonad (IKG), dan kadar estradiol. Penelitian dilakukan secara eksperimental menggunakan rancangan acak lengkap dengan tiga perlakuan dan delapan ulangan. Perlakuan percobaan terdiri atas induksi hormon $\mathrm{GnRH}$-analog dengan dosis 0,0;0,5 dan 1,0 ml kg-1 bobot badan. Ikan sidat dengan rata-rata ukuran panjang $67 \mathrm{~cm}$ dan rata-rata bobot $500 \mathrm{~g}$ sebanyak 18 ekor yang telah diinduksi dengan berbagai dosis $\mathrm{GnRH}$ analog $\left(0,0,5 \mathrm{dan} 1 \mathrm{ml} \mathrm{kg}{ }^{-1}\right.$ bobot badan) dipelihara dalam akuarium fiberglass selama dua bulan. Pakan berupa ikan rucah diberikan satu kali sehari pada pukul 16.00 secara ad libitum. Variabel yang diamati adalah indeks mata, IKG, dan kadar estradiol. Hasil penelitian menunjukkan bahwa induksi hormon GnRHanalog tidak berpengaruh terhadap peningkatan nilai indeks mata, nilai IKG $(\mathrm{p}>0,05)$, dan kadar estradiol ikan sidat $(\mathrm{p}<0,05)$. Induksi hormon GnRH-analog dengan dosis 0,5 dan $1 \mathrm{ml} \mathrm{kg}^{-1}$ bobot badan tidak efektif memacu pematangan gonad ikan sidat.
\end{abstract}

Kata penting: estradiol, GnRH-analog, indeks kematangan gonad, indeks mata, sidat

\begin{abstract}
Eel, Anguilla bicolor McClelland was hard to mature in captivity, due to low levels of pituitary gonadotropin. In order to stimulate gonadal maturation in captivity, exogenous gonadotropin is needed. The purpose of this study was to assess the effect of GnRH-analog induction on gonadal maturation of tropical eel base on the value of the eye index, gonadosomatic index, and estradiol levels. The study was carried out experimentally with a completely randomized design with three treatments and eight replications. The treatments were the induction of hormone GnRH-analogues with doses of $0.0 ; 0.5$ and $1.0 \mathrm{ml} \mathrm{kg}$-1 body weight. Eel with an average total length of $67 \mathrm{~cm}$ and an average weight of $500 \mathrm{~g}$ were injected with different doses of GnRH-analog $\left(0.0 ; 0.5\right.$ and $1.0 \mathrm{ml} \mathrm{kg} \mathrm{k}^{-1}$ body weight), kept in the fiberglass aquarium for two months. The eels were fed with discard fish daily in ad libitum at $16.00 \mathrm{pm}$. The observed variables were eye index, Gonadosomatic Index (GSI), and estradiol levels. The results showed that injection of three different doses of GnRH-analog did not affect on the increasing of GSI, eye index $(\mathrm{P}>0.05)$, and estradiol $(\mathrm{P}<0.05)$. Induction of GnRH-analog of $0.0 ; 0.5$ and $1.0 \mathrm{ml} \mathrm{kg}^{-1}$ body weight can not stimulate the gonadal maturity of tropical eel.
\end{abstract}

Keyword: GnRH-analog, estradiol, eye index, gonadosomatic index, eel, Anguilla bicolor.

\section{Pendahuluan}

Ikan sidat merupakan ikan katadrom. Pada fase pertumbuhan (yellow eel) ikan hidup di perairan tawar. Setelah mencapai pubertas (silver eel) ikan sidat akan beruaya ke perairan laut untuk memijah (Geffroy et al. 2012, Nowosad et al. 2014). Fase pubertas pada masing-masing jenis

$\square$ Penulis korespondensi

Alamat surel: farida.rachmawati@unsoed.ac.id kelamin berbeda antara individu jantan dan betina. Ikan jantan mencapai pubertas pada ukuran panjang tubuh $>43,7 \mathrm{~cm}$, sedangkan ikan betina mencapai pubertas pada ukuran panjang tubuh $>57,5 \mathrm{~cm}$ (Sudo et al. 2013). Setelah memijah ikan sidat akan mati karena ikan sidat termasuk kedalam kelompok hewan smelparous (Moyes \& Schulte 2008). 
Sampai saat ini budi daya ikan sidat Anguilla bicolor McClelland masih terfokus pada usaha pembesaran, sehingga kebutuhan benih selalu dipasok dari alam. Pada umumnya ikan sidat yang dibudidayakan berukuran panjang tubuh mulai dari ukuran $20 \mathrm{~cm}$ hingga $50 \mathrm{~cm}$. Menurut Kasimoglu (2014), umur 3 tahun ikan sidat berukuran panjang $\pm 23 \mathrm{~cm}$, umur 4 tahun panjang $\pm 27 \mathrm{~cm}$, umur 5 tahun panjang $\pm 35 \mathrm{~cm}$, umur 6 tahun panjang $\pm 45 \mathrm{~cm}$, dan pada umur 7 tahun panjang mencapai $50 \mathrm{~cm}$.

Ikan sidat sulit matang gonad dalam kondisi budi daya sehingga pemijahan secara buatan sulit dilakukan (Denusta et al. 2014). Berbagai penelitian telah dilakukan dalam upaya untuk memacu pematangan gonad ikan sidat dengan cara memanipulasi faktor lingkungan yang berupa salinitas, temperatur, dan induksi hormon, namun demikian kematangan gonad tahap akhir sangat bergantung pada kadar hormon steroid (Sabet et al. 2009, Nowosad et al. 2014). Hormon steroid mempunyai peran yang sangat penting pada proses fisiologi vertebrata, khususnya reproduksi (Zohar et al. 2001).

Penelitian yang dilakukan pada ikan sidat subtropis $A$. japonica dan $A$. anguilla menunjukkan bahwa pemberian gonadotropin berpengaruh terhadap perkembangan gonad (Jung Kim et al. 2007, Palstra et al. 2005). Induksi hormon eksogen menjadi faktor yang sangat penting untuk memacu pematangan gonad ikan sidat. Induksi hormon bertujuan untuk meningkatkan kadar hormon endogen sehingga akan memengaruhi aktivitas gonad. Beberapa hormon yang telah digunakan pada studi terdahulu pada ikan sidat sub tropis antara lain, Salmon Pituitary Extract, $20 \beta$-dyhidroxi-4-pregnen-3-one pada A. japonica (Kagawa et al. 2005), A. australis (Palstra et al. 2005, Burgerhout et al. 2011), HCG ( Human Chorionic Gonadotropin) pada A. japonica (Ohta
\& Tanaka 1997), A. anguilla (Gallego et al. 2012), ekstrak pituitari ikan mas (Rovara 2008), PMSG, antidopamin dan estradiol- $17 \beta$ (Tomasoa et al. 2015) pada $A$. bicolor.

Peningkatan kematangan gonad ikan sidat dapat diamati dari perubahan nilai indeks kematangan gonad (IKG), indeks mata, indeks sirip, kadar hormon steroid (Nowosad et al. 2014), diameter telur, fekunditas dan kualitas spermatozoa. Nilai IKG A. bicolor yang diinduksi ekstrak hipofisis dengan dosis 0,5 yang diberikan setiap minggu selama 10 minggu sebesar 3,37\% (Rovara et al. 2008). Nilai IKG ikan sidat betina yang belum matang gonad sebelum beruaya berkisar antara 1-4\%, sedangkan pada umumnya nilai IKG ikan sidat matang gonad yang sudah beruaya mencapai 40\% (Tsukamoto et al. 2011).

Keberhasilan induksi hormon sangat bergantung kepada respons hormonal dan kinerja reproduksi ikan, yang bervariasi bergantung kepada titer hormon endogen. Kinerja reproduksi ikan sangat dipengaruhi oleh aktivitas kelenjar endokrin yang mensintesis dan mensekresi hormon. Kelenjar pensekresi hormon yang terlibat dalam reproduksi meliputi hipotalamus (otak), pituitari, dan gonad. Stimulus dari faktor lingkungan akan memicu hipotalamus mensintesis dan mensekresi hormon pelepas gonadotropin $(\mathrm{GnRH})$ (Kagawa et al. 2005). GnRH selanjutnya memengaruhi pituitari untuk mensintesis dan melepas hormon gonadotropin yang diperlukan untuk steroidogenesis dan perkembangan gonad (Yamaguchi et al. 2006). Gonad pada akhirnya akan memberikan umpan balik kepada pituitari untuk mengontrol sintesis dan pelepasan hormon gonadotropin (Yaron et al. 2003). Diantara steroid yang disekresi gonad yang terlibat dalam umpan balik positif dan negatif pada pituitari adalah estradiol$17 \beta$ (E2), testoterone (T), dan 11-ketotestoterone (11-KT) (Yamaguchi et al. 2006). 
Gonadotropin hormone $(\mathrm{GtH})$, yaitu folicle stimulating hormone (FSH) dan luteinizing hormone (LH) mempunyai peran yang sangat penting dalam mengatur proses reproduksi pada Vertebrata melalui aksi poros otak - pituitari -gonad (Yamaguchi et al. 2006, Oliveira et al. 2014, Rousseau et al. 2014). Pada Teleostei, hipotalamus mengatur sekresi GtH melalui berbagai neuromediator seperti Gonadotropin Releasing Hormone $(\mathrm{GnRH})$ dan neurotransmitter (dopamin, norepinephrin, dan serotonin). Pada ikan, GtH bekerja pada gonad untuk merangsang produksi hormon-hormon steroid, yang selanjutnya akan mengatur sintesis vitelogenin, perkembangan gonad, kematangan gonad tahap akhir dan aktivitas reproduksi lainnya ( Levavi-Sivan et al. 2010).

GnRH-analog merupakan hormon steroid yang mengandung ekstrak hipofisis ikan salmon dan antidopamin. Ekstrak salmon pituitari merupakan hormon yang digunakan untuk memacu pematangan gonad betina, sedangkan Human Chorionic Gonadotropin (HCG) digunakan untuk ikan jantan ( (Kazeto et al. 2011). Penggunaan GnRH-analog untuk induksi ikan sidat $A$. bicolor belum pernah dilakukan, dengan demikian menarik untuk dikaji bagaimana pengaruh induksi GnRH-analog terhadap kinerja reproduksinya.

Penelitian ini bertujuan untuk mengkaji pengaruh induksi GnRH-analog terhadap pematangan gonad ikan sidat dilihat dari perubahan nilai indeks mata, IKG, dan kadar estradiol.

\section{Bahan dan metode}

Penelitian dilaksanakan pada bulan Juli hingga Oktober 2014. Obyek penelitian adalah ikan sidat Anguilla bicolor McClelland dengan ukuran panjang tubuh rata-rata $67 \mathrm{~cm}$ (fase silver eel). Ikan uji diperoleh dari nelayan pengepul ikan sidat di sekitar Sungai Serayu, Kabupaten Cilacap, Provinsi Jawa Tengah. Bahan yang digunakan meliputi pakan ikan (ikan rucah), hormon GnRH-Analog (Syndal, Vancouver Cana$d a)$, kit hormon steroid Vidas Elisa kit $17 \beta$-estradiol (REF 30330 - BioMarieux, Inc. Perancis). Alat yang digunakan yaitu mikrosentrifuga, tabung sentrifuga, akuarium fiber, freezer, alat bedah, timbangan teknikal, dan timbangan analitik.

Percobaan dilakukan dalam skala laboratorium, menggunakan rancangan acak lengkap dengan tiga perlakuan dosis hormon GnRH-Analog (0, 0,5 , dan $1 \mathrm{ml} \mathrm{kg}^{-1}$ bobot badan (bb), masingmasing perlakuan diulang sebanyak delapan kali. Ikan sidat terlebih dahulu diaklimasi selama satu minggu pada bak fiber berdiameter $125 \mathrm{~cm}$ dan tinggi $70 \mathrm{~cm}$ serta diisi air sebanyak 300 liter. Selama aklimasi ikan sidat diberi pakan ikan rucah secara ad libitum.

Setelah aklimasi ikan ditempatkan dalam akuarium fiber berukuran $100 \times 100 \times 130 \mathrm{~cm}^{3}$ sesuai dengan perlakuan yang dicobakan dengan padat penebaran 8 ekor. Ikan diberi pakan ikan rucah satu kali sehari yaitu pada pukul 16.00 sebanyak 3\% dari biomassa ikan dan dipelihara selama delapan minggu. Penyuntikan hormon dilakukan secara intraperitonial pada bagian abdomen ikan dengan menggunakan hormon GnRHAnalog (0, 0,5 dan $\left.1 \mathrm{ml} \mathrm{kg}^{-1} \mathrm{bb}\right)$ setiap minggu sekali selama delapan minggu. Variabel yang diamati adalah indeks mata, indeks kematangan gonad (IKG), dan kadar estradiol.

Preparasi sampel darah untuk analisis hormon dilakukan di Laboratorium Fisiologi Hewan Fakultas Biologi Unsoed, Purwokerto. Pengukuran kadar estradiol dengan metode ELISA dilakukan di Laboratorium Medico, Purwokerto.

Pengukuran indeks mata dilakukan menggunakan penggaris dengan mengukur diameter orbital secara horisontal dan vertikal. Rumus perhitungan indeks mata mengacu pada Yokouchi et al. (2009): 
Indeks mata : $\{(\mathrm{A}+\mathrm{B}) / 4\}^{2} \mathrm{x} \pi / \mathrm{TL} \times 100$

Keterangan: $\mathrm{A}=$ diameter orbital horisontal $(\mathrm{mm}), \mathrm{B}=$ diameter orbital vertikal $(\mathrm{mm}), \mathrm{TL}=$ panjang tubuh total (mm)

Sebelum dilakukan pengambilan sampel darah, ikan sidat dibius terlebih dahulu menggunakan eugenol dengan dosis 50 ppm selama 30 menit (Rachmawati \& Susilo 2009). Setelah pingsan, ditimbang bobotnya dan diukur panjangnya lalu diambil darahnya melalui pembuluh darah kaudal dengan menggunakan siring berukuran 1 ml. Darah yang diperoleh dimasukkan kedalam tabung mikro sentrifuga, kemudian darah dibiarkan membeku pada suhu ruang selama 30 menit. Selanjutnya darah disimpan selama \pm 12 jam pada suhu $4^{\circ} \mathrm{C}$, setelah itu disentrifugasi selama 15 menit dengan kecepatan 3500 rpm untuk mendapatkan serum. Serum darah yang dihasilkan dimasukkan ke dalam tabung mikro sentrifuga dan disimpan pada suhu $-20^{\circ} \mathrm{C}$, selanjutnya digunakan untuk analisis kadar hormon etradiol dengan metode ELISA.
Ikan sidat yang telah diambil darahnya lalu dibedah untuk diisolasi gonadnya. Gonad ditimbang bobotnya untuk menghitung nilai IKG (Indeks Kematangan Gonad) (Kagawa 2005):

$\mathrm{IKG}=($ bobot gonad / bobot tubuh $) \times 100$

Data hasil penelitian yang berupa indeks mata, IKG, dan kadar estradiol diuji dengan analisis ragam (Anova), dengan tingkat kepercayaan 95\% (Steel \& Torrie 1981).

\section{Hasil}

Berdasarkan hasil penelitian terhadap ikan sidat yang diinduksi GnRH-analog dengan dosis 0, 0,5 dan $1 \mathrm{ml} \mathrm{kg}^{-1} \mathrm{bb}$, diperoleh nilai indeks mata rata-rata ikan masing-masing 8,$7 ; 7,5$; dan 7,4 (Gambar 1), nilai IKG rata-rata masingmasing perlakuan adalah $1,78 \%, 1,23 \%$, dan 1,26\% (Gambar 2), dan kadar estradiol berturutturut adalah $0,67 \mathrm{ng} \mathrm{ml}^{-1}, 0,25 \mathrm{ng} \mathrm{ml}^{-1}$, dan 0,22 ng $\mathrm{ml}^{-1}$ (Gambar 3).

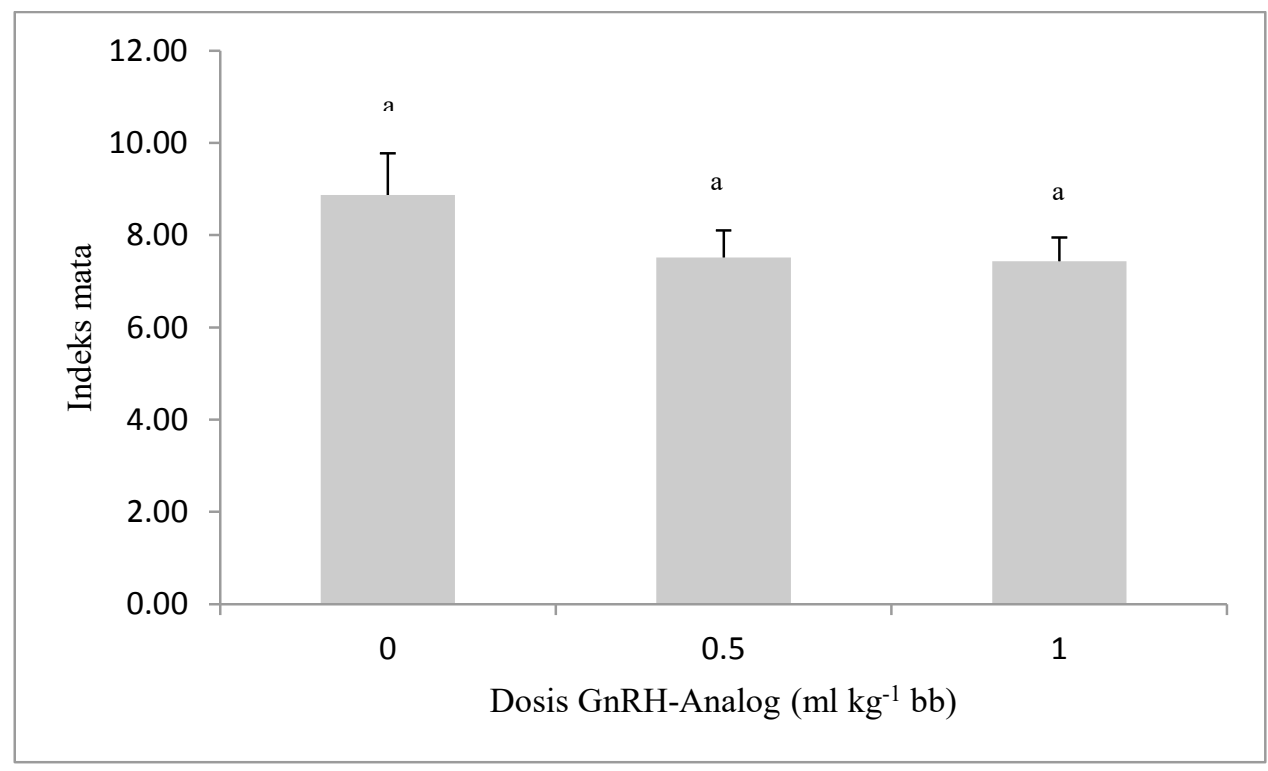

Gambar 1 Rata-rata nilai indeks mata Anguilla bicolor McClelland yang diinduksi dengan GnRH-Analog dosis $0,0,5$ dan $1 \mathrm{ml} \mathrm{kg}^{-1} \mathrm{bb}$. Huruf yang sama di atas kolom menunjukkan hasil yang tidak berbeda nyata $(\mathrm{P}>0,05)$ 


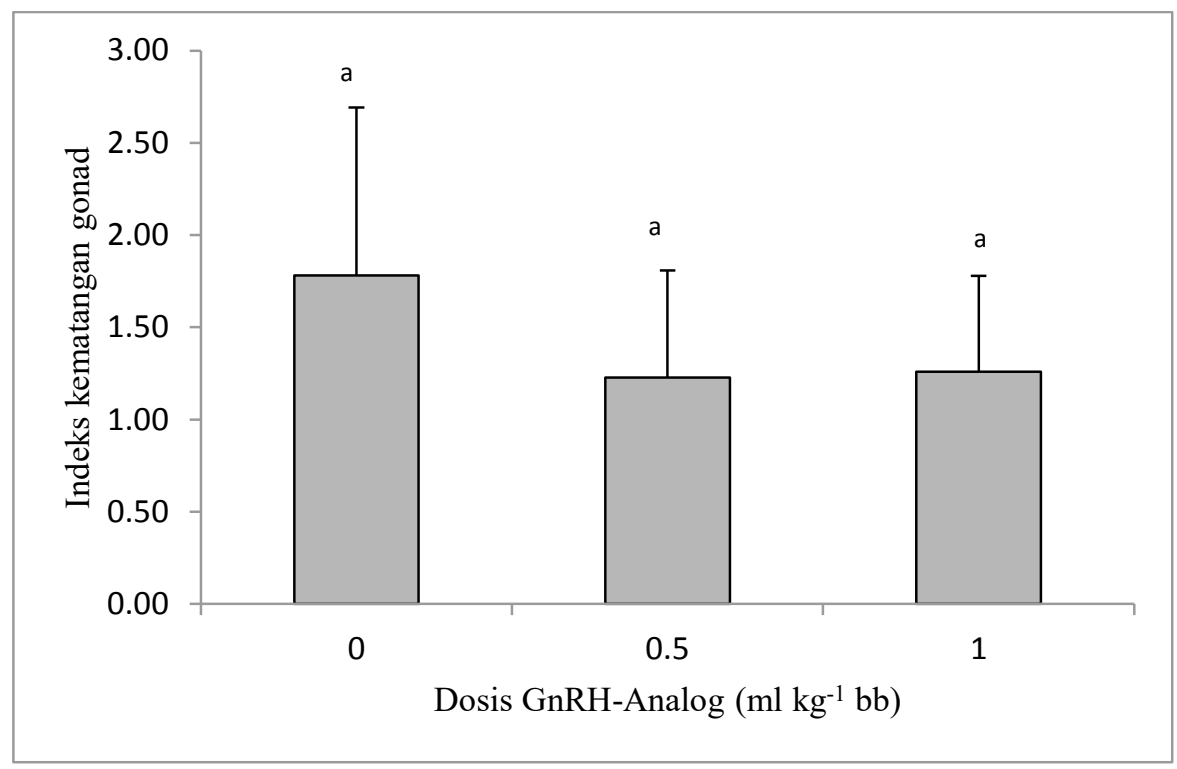

Gambar 2 Rata-rata nilai indeks kematangan gonad Anguilla bicolor McClelland yang diinduksi dengan GnRH-Analog dosis 0, 0,5 dan $1 \mathrm{ml} \mathrm{kg}^{-1} \mathrm{bb}$. Huruf yang sama di atas kolom menunjukkan hasil yang tidak berbeda nyata $(\mathrm{P}>0,05)$

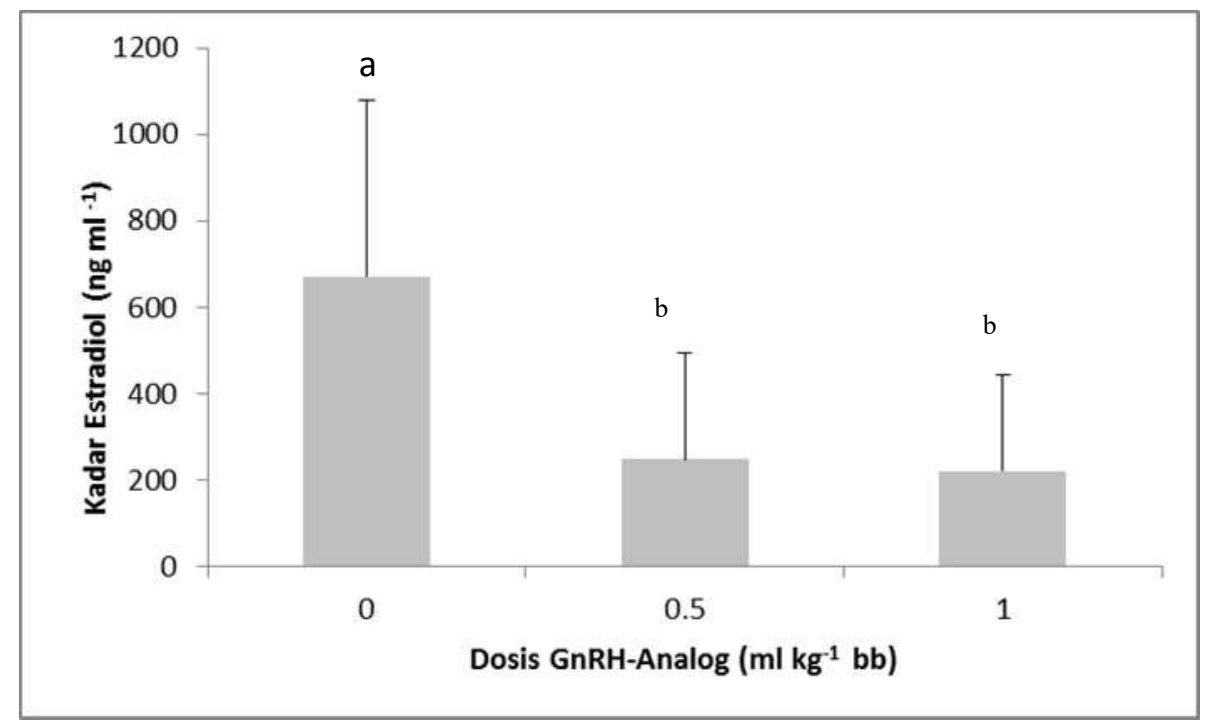

Gambar 3 Rata-rata kadar estradiol Anguilla bicolor McClelland yang diinduksi dengan GnRH-Analog dosis $0,0,5$ dan $1 \mathrm{ml} \mathrm{kg}^{-1}$ bb Huruf yang berbeda di atas kolom menunjukkan hasil yang berbeda nyata $(\mathrm{P}<0,05)$

Hasil analisis ragam menunjukkan bahwa perlakuan induksi GnRH-analog berpengaruh tidak nyata terhadap indeks mata dan IKG (P > 0,05) dan berpengaruh sangat nyata terhadap penurunan kadar estradiol $(\mathrm{P}<0,05)$. Induksi GnRH-analog dengan dosis 0,5 dan $1 \mathrm{ml} \mathrm{kg}^{-1} \mathrm{bb}$ belum efektif memacu kematangan gonad ikan.
Hal ini dapat dilihat dari nilai indeks mata dan IKG yang relatif sama pada setiap perlakuan (Gambar 1 dan 2). Sementara kadar estradiol pada perlakuan yang diinduksi GnRH-analog dengan dosis 0,5 dan $1 \mathrm{ml} \mathrm{kg}^{-1}$ bb lebih rendah dibanding perlakuan kontrol $\left(\begin{array}{llll}0 & \mathrm{ml} & \mathrm{kg}^{-1} & \mathrm{bb}\end{array}\right)$ (Gambar 3). 


\section{Pembahasan}

Ikan sidat yang digunakan pada penelitian ini berada pada fase pubertas (silver eel). Namun, tidak seperti pada ikan umumnya, meskipun sudah memasuki fase pubertas, ikan sidat belum siap memijah karena untuk memijah ikan tersebut harus beruaya ke perairan laut. Selama beruaya, gonad ikan sidat akan mengalami pematangan sampai tercapai kematangan gonad tahap akhir dan siap untuk memijah (Van den Thillart \& Dufour 2009). Dengan demikian induksi hormonal yang dilakukan pada ikan sidat hanya bertujuan memacu kematangan gonad tahap awal, karena secara alami di alam sidat butuh waktu yang cukup lama untuk mencapai kematangan gonad tahap awal bila tanpa manipulasi faktor lingkungan maupun hormonal (Nowosad et al. 2014)

Nilai indeks mata akan meningkat sejalan dengan peningkatan kematangan gonad, selain itu pada saat ikan sidat beruaya ke perairan laut indeks mata juga akan meningkat. Nilai rata-rata indeks mata pada masing-masing perlakuan adalah 8,87 (kontrol), 7,52 (induksi GnRH-analog 0,5 $\mathrm{ml} \mathrm{kg}^{-1} \mathrm{bb}$ ), dan 7,43 (induksi GnRH-analog $1 \mathrm{ml} \mathrm{kg}{ }^{-1} \mathrm{bb}$ ). Nilai indek mata yang berkisar antara 7,52-8,87 menunjukkan bahwa ikan sidat yang digunakan dalam penelitian ini berada pada fase pubertas (silver eel). Menurut Beullens et al. (1997), nilai indeks mata $>6,7$ sudah mencapai fase pubertas. Meskipun pada penelitian ini ikan sidat sudah mencapai fase pubertas, namun belum mencapai matang gonad. Pematangan gonad akan berlangsung seiring dengan proses ruaya ke perairan laut (Van den Thillart \& Dufour 2009). Nilai indeks mata pada $A$. anguilla yang sudah matang gonad sebesar 15,75 (Mordenti et al. 2012).

Nilai IKG ikan sidat pada masing-masing perlakuan relatif sama tidak berbeda nyata $(p>0,05)$ masih di bawah $2 \%$, sedangkan ikan sidat fase silver di alam mempunyai nilai IKG 2,88\% (Rachmawati \& Susilo 2012). Hasil penelitian Rovara et al. (2008) yang menggunakan ekstrak hipofisis ikan mas dengan dosis $1 / 2$, berhasil memacu kematangan gonad yang tecermin pada peningkatan nilai IKG hingga mencapai $3,37 \%$.

Nilai indeks mata dan IKG antar perlakuan tidak berbeda nyata menunjukkan bahwa dosis GnRH-analog yang diberikan belum mampu memacu peningkatan kematangan gonad. Diduga dosis hormon yang diberikan tidak tepat melampaui batas optimum, karena pada umumnya pemberian $\mathrm{GnRH}$-analog untuk ikan adalah 0,3 ml $\mathrm{kg}^{-1} \mathrm{bb}$. Penelitian yang dilakukan pada ikan lele dumbo, induksi GnRH-analog dengan dosis 0,3 $\mathrm{ml} \mathrm{kg}{ }^{-1}$ bb memberikan hasil yang lebih baik terhadap lama waktu pemijahan, daya tetas telur dan sintasan larva dibanding dengan dosis 0,6 dan 0,93 $\mathrm{ml} \mathrm{kg}^{-1}$ bb (Sinjal 2014).

Induksi hormon eksogen yang tinggi akan menjadi umpan balik negatif bagi sekresi GnRH endogen, sehingga sekresi hormon eksogen menjadi terhambat (Moyes \& Schulte 2008). Kemampuan kelenjar hipofisis anterior untuk bereaksi terhadap pemberian hormon GnRH tidak selalu sama. Dosis yang tinggi akan menyebabkan terhentinya produksi gonadotropin, setelah terlebih dahulu mengalami periode perangsangan awal (initial stimulation/flare-up effect) (Suparman \& Suparman 2016).

Pada ikan sidat betina, nilai IKG berkorelasi positip dengan titer hormon estradiol. Pada penelitian ini dapat dipastikan bahwa jenis kelamin ikan sidat yang digunakan merupakan ikan betina. Jenis kelamin ikan betina mudah dikenali dari bentuk morfologi gonad berupa lamela, sedangkan ikan sidat jantan mempunyai struktur gonad berupa lobulus. 
Hasil pengukuran kadar estradiol rata-rata pada masing-masing perlakuan berturut-turut yaitu $0,67 \mathrm{ng} \mathrm{ml}^{-1}$, (kontrol), 0,25 $\mathrm{ng} \mathrm{ml}^{-1}$ (induksi GnRH-analog 0,5ml kg-1 bb) dan 0,22 $\mathrm{ng} \mathrm{ml}^{-1}$ (induksi GnRH-analog $1 \mathrm{ml} \mathrm{kg}^{-1} \mathrm{bb}$ ). Kadar estradiol akan meningkat seiring dengan peningkatan kematangan gonad yang tercermin pada nilai IKG (Rachmawati \& Susilo 2011). Estradiol berperan pada kematangan gonad dan merangsang sintesis vitelogenin di hati, sebagai prekusor yolk untuk menyokong pertumbuhan oosit (Kagawa et al. 1981, Matsubara et al. 2005, Levavi-Sivan et al. 2010, Kazeto et al. 2011).

Perlakuan induksi memberikan kadar estradiol yang lebih rendah dibanding perlakuan kontrol. Diduga frekuensi induksi setiap minggu sekali memacu kondisi stres bagi ikan sehingga berpengaruh terhadap kinerja reproduksinya. Hal ini dikarenakan pada penelitian ini tidak dilakukan pembiusan pada saat induksi, sehingga berdampak stress bagi ikan.

Dugaan adanya stres pada ikan sidat tecermin dari rendahnya kadar estradiol pada penelitian ini yaitu masing-masing $0,25 \mathrm{ng} \mathrm{ml}^{-1}$ (induksi GnRH-analog 0,5 $\mathrm{ml} \mathrm{kg}^{-1} \mathrm{bb}$ ) dan $0,22 \mathrm{ng} \mathrm{ml}^{-1}$ (induksi GnRH-analog $1 \mathrm{ml} \mathrm{kg}^{-1} \mathrm{bb}$ ) dibanding dengan kadar estradiol ikan sidat yang tidak diberi perlakuan induksi sebesar $0,67 \mathrm{ng} \mathrm{ml}^{-1}$. Stres pada ikan dapat dipicu oleh aktivitas transportasi, penanganan ikan pada kondisi budi daya, dan faktor-faktor lingkungan. Perlakuan induksi merupakan salah satu faktor yang dapat memicu stres bagi ikan apabila tidak diikuti dengan pembiusan.

Induksi GnRH-analog dengan dosis 0, 0,5 dan $1 \mathrm{ml} \mathrm{kg}^{-1} \mathrm{bb}$ terhadap ikan sidat fase silver pada penelitian ini tidak berpengaruh terhadap peningkatan kematangan gonad. Hal ini diduga karena tingginya dosis hormon yang diberikan sehingga menjadi umpan balik negatif bagi se- kresi hormone endogen (Moyes \& Schulte 2008). Selain itu, perlakuan induksi yang tidak diikuti dengan pembiusan memicu stres pada ikan sidat.

Stres ikan pada perlakuan induksi dapat dikurangi dengan pemberian obat bius (Tomasoa et al. 2015, Zahri et al. 2015). Obat bius atau anestesi mampu menghambat kerja kortikosteroid sehingga sekresi kortisol sebagai respon stres pada hewan dihambat (Husen \& Sarma 2014). Berdasarkan hasil penelitian ini maka disarankan untuk membius ikan sebelum diinduksi.

\section{Simpulan}

Induksi GnRH-Analog dengan dosis 0,5 dan $1 \mathrm{ml} \mathrm{kg}^{-1} \mathrm{bb}$ tidak berpengaruh terhadap peningkatan kematangan gonad ikan sidat Anguilla bicolor McClelland yang tercermin pada nilai indeks mata, indeks kematangan gonad, dan kadar estradiol yang masih rendah.

\section{Persantunan}

Penulis mengucapkan terima kasih yang tak terhingga kepada Kementerian Riset, Teknologi, dan Pendidikan Tinggi yang mendanai penelitian ini dalam skim penelitian Hibah Bersaing tahun Anggaran 2014/2015.

\section{Daftar pustaka}

Beullens K, Eding EH, Gilson P, Ollevier F, Komen J \& Richter CJJ. 1997. Gonadal differentiation, intersexuality and sex ratios of European eel (Anguilla anguill L) maintained in captivity. Aquaculture, 153(1-2): 135-150.

Burgerhout E, Brittijn SA, Kurwie T, Decker P, Dirks RP, Palstra AP, Spaink HP, Van den Thillart GEEJM. 2011. First artificial hybrid of the eel species Anguilla australis and Anguilla anguilla. BioMed Central Developmental Biology, 11(16): 1-9.

Gallego V, Mazzeo I, Vilchez MC, Penaranda DS, Carneiro PCF, Perez L, Asturiano JF. 2012. Study of the effects of thermal regime and alternative hormonal treatments on the reproductive performance of European eel 
males (Anguilla anguilla) during induced sexual maturation. Aquaculture, 354(1): 716.

Geffroy B, Fostier A, Guiguen Y, Bardonnet A. 2012. Unusual cases of adult intersexuality in the European eel Anguilla Anguilla. Sexual Development, 6(6): 316-319.

Denusta PJT, de Jesus-Ayson EGT, Laron MA, Garcia LMB. 2014. Effects of human chorionic gonadotropin (HCG) and handling stress on spermiation of silver perch Leiopotherapon plumbeus (Kner, 1864). Journal of Applied Ichthyology, 30(3): 448-453.

Husen MdA, Sharma S. 2014. Efficacy of anesthetics for reducing stress in fish during aquaculture practices - A Review. Journal of Science, Engineering and Technology, 10(1): 104-123

Jung Kim D, Young Bae J, Oh Kim E. 2007. Changes in sex steroid hormones and ovarian development during artificial maturation of female eel, Anguilla japonica. Integrative Biosciences, 11(2): 117-124.

Kagawa H, Takano K, Nagahama Y. 1981. Correlation of plasma estradiol-17 $\beta$ and progesterone levels with ultrastructureand histochemistry of ovarian follicles in the whitespotted char, Salvelinus leucomaenis. Cell and Tissue Research, 218(2): 315-329.

Kagawa H, Tanaka H, Ohta H, Unuma T, Nomura K. 2005. The first success of glass eel production in the world: Basic biology on fish reproduction advances new applied technology in aquaculture. Fish Physiology and Biochemistry, 31(2-3): 193-199.

Kasimoglu C. 2014. The Effect of Fish Size, Age and condition factor on the contents of seven essential elements in Anguilla anguilla from Tersakan Stream Mugla (Turkey). Journal of Pollution Effects \& Control, 2(2): 123-129.

Kazeto Y, Tosaka R, Matsubara H, Ijiri S, Adachi S. 2011. Ovarian steroidogenesis and the role of sex steroid hormones on ovarian growth and maturation of the Japanese eel. Journal of Steroid Biochemistry and Molecular Biology, 127(3-5): 149-154.

Levavi-Sivan B, Bogord J, Monanos EL, Gomes A, Laroyne JJ. 2010. Perspectives on fish gonadotropins and their receptors. General and Comparative Endocrinology, 165(3): 412-437.
Matsubara H, Lokman PM, Kazeto Y, Adachi S, Yamauchi K. 2005. Serum steroid profiles in artificially maturing female Japanese eel, Anguilla japonica. Aquaculture, 243(1-4): 392-402.

Mordenti O, Di Biase A, Sirri R, Modugno S, Tasselli A. 2012. Induction of sexual maturation in wild female European eels ( $A n$ guilla anguilla) in darkness and light. The Israeli Journal of Aquaculture, 64(1): 1-9.

Moyes CD, Schulte PM. 2008. Principles of Animal Physiology, second edition. Pearson, Benjamin Cummings, San Francisco, Boston, New York. $754 \mathrm{p}$

Nowosad J, Kucharczyk D, Czarkowski TK, Kwasek K. 2014. Changes in body weight and eye size in European eel kept in fresh and salt water. Italian Journal of Animal Science, 13(2): 382-386.

Ohta H, Tanaka H. 1997. Relationship between serum levels of human chorionic gonadotropin (hCG) and 11-ketotestosterone after a single injection of hCG and induced maturity in the male Japanese eel, Anguilla japonica. Aquaculture, 153(1-2): 123-134.

Oliveira AD, Levavi-Sivan B, Aizin J, Gonzalves J, Fernandez-Duran B, Coimbra J. 2014. Pituitary Follicle-stimulating hormone (FSH) and luteinizing hormone (LH) levels in maturing female flounder Platichthys flesus under hydrostatic pressure simulating vertical migrations. Marine Biology Research, 10(1): 85-92.

Palstra AP, Cohen EGH, Niemantsverdriet PRW, van Ginneken VJT, van den Thillart GEEJM. 2005. Artificial maturation and reproduction of Europian silver eel : Development of oocytes during final maturation. Aquaculture, 249(1-4): 533-547.

Rachmawati FN, Susilo U. 2009. Perkembangan gonad ikan sidat, Anguilla bicolor ditinjau dari titer hormon gonadotropin. Sains Akuatik 10(2): 148-154.

Rachmawati FN, Susilo U. 2011. Profil hormon dan kinerja reproduksi ikan sidat, Anguilla bicolor McCleland. Biota, 16(2): 221-226.

Rachmawati FN, Susilo U.2012. Kajian histologi ovarium ikan sidat Anguilla bicolor McClelland yang tertangkap di Segara Anakan Cilacap. Berkala Penelitian Hayati, 18(1): 4749. 
Rousseau K, Lafont AG, Pasquier J, Mauger G, Jolly C, Sebert ME, Aroua S, Pasqualini C, Dufour S. 2014. Advances in eel reproductive physiology and endocrinology. In: Trischitta F, TakeiY, Sebert P (Editor). Eel Physiology. CRC Press. Taylor \& Francis Group, New York. pp. 1-42.

Rovara O, Affandi R, Zairin Yunior M, Agungpriyono S, Toelihere MR. 2008. Pematangan gonad ikan sidat betina (Anguilla bicolor bicolor) melalui penyuntikan ekstrak hipofisasi. Jurnal Ilmu-ilmu Perairan dan Perikanan Indonesia, 15(1): 69-76.

Sabet S, Imanpoor S, Mohammad, Reza, Fatideh A, Bagher, Gorgin, Saeed. 2009. Study on sexual maturity and levels of gonad steroid hormones in female kutum Rutilus frisii $\mathrm{ku}$ tum (Kamenskii, 1901) during spawning season from river Sefid-Rood of the southern Caspian Sea. Journal of Cell and Animal Biology, 3(11): 208-215.

Sinjal H. 2014. Efektifitas ovaprim terhadap lama waktu pemijahan, daya tetas telur dan sintasan larva ikan lele dumbo, Clarias gariepinus. Budidaya Perairan, 2(1): 14-21

Steel RGD, Torrie JH. 1981. Principles and Procedures of Statistic a Biometrical Approach, $2^{\text {nd }}$ edition. Mc Graw Hill Book Company, Singapore. $672 \mathrm{p}$

Sudo R, Fukuda N, Aoyama J, Tsukamoto K. 2013. Age and body size Of Japanese eels, Anguilla japonica, at the silver-stage in the Hamana Lake system, Japan. Coastal Marine Science, 36(1): 13-18.

Suparman E, Suparman E. 2016. Peran GnRH agonis. Jurnal Biomedik, 8(1): 1-7

Tomasoa AM, Sudrajat AO, Zairin Yunior M. 2015. Induksi pemetangan gonad ikan sidat menggunakan PMSG, antidopamin, dan estradiol-17ß. Jurnal Akuakultur Indonesia, 14(2): 112-121.
Tsukamoto K, Chow S, Otake T, Kurogi H, Mochioka N, Miller M, Aoyama J, Kimura S, Watanabe S, Yoshinaga T, Shinoda A, Kuroki M, Oya M, Watanabe T, Hata K, Ijiri S, Kazeto Y, Nomura K, Tanaka \& H. 2011. Oceanic spawning ecology of freshwater eels in the western North Pacific. $\mathrm{Na}$ ture Communications, 2(179): 1-9.

Van den Thillart G, Dufour S. 2009. How to estimate the reproductive succes of European silver eels. In: Van den Thillart G, Rankin J, Dufour S (editor). Spawning Migration of the European Eel. Springer, Netherland. pp. 3-9

Yamaguchi S, Gen K, Okuzawa K, Matsuyama M, Kagawa H. 2006. Influence of estradiol$17 \beta$, tetstosteron, and 11-ketotestosterone on testicular development, serum steroid hormone and gonadotropin secretion in male red sea bream Pagrus major. Fisheries Science, 72(4): 835-845.

Yaron Z, Gur G, Melamed P, Rosenfeld H, Elizur A, Levavi-Sivan B. 2003. Regulation of fish gonadotropins. International Review of Cytology, 225(1): 131-185.

Yokouchi K, Sudo R, Kaifu K, Aoyama J, Tsukamoto K. 2009. Biological characteristics of silver-phase Japanese eels, Anguilla japonica, Collected from Hamana Lake, Japan. Coastal Marine Science. 33 (1): 1-10.

Zahri A, Sudrajat AO, Zairin Yunior M. 2015. Pertumbuhan gonad sidat Anguilla bicolor bicolor yang diinduksi kombinasi hormone HCG, MT, E2 dan antidopamin. Jurnal Akuakultur Indonesia, 14(1): 69-78.

Zohar Y, Mylonas CC. 2001. Endocrine manipulations of spawning in cultured fish: from hormone to genes. Aquaculture, 197(1-4): 99-136. 